\title{
CHRISTIAN RELIGION AND WELL-BEING
}

\author{
Esmari Faull \\ Christian Spirituality \\ University of South Africa
}

\begin{abstract}
Some researchers have defined well-being as being content, happy, healthy and prosperous. It consists of experiencing enjoyment, completeness, and meaning, rather than merely avoiding pain and conflict. To experience personal well-being it is necessary that all aspects of being function in a healthy manner. Research on the relationship between the Christian religion and well-being has concluded that nurturing, non-punitive religion is associated with mental and physical health, and that active participation in church activities that enhances the member's social support system can be beneficial.
\end{abstract}

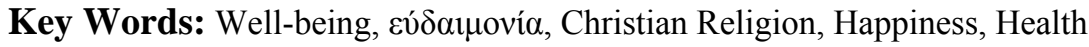

\section{Introduction}

This article focuses on how the Christian religion might contribute to or detract from wellbeing, for example in contributing to life satisfaction, morale, happiness, positive emotions such as hopefulness, meaning and purpose, and other indicators of a life that is flourishing. It aims to provide an overview of some of the conclusions that has been reached by scholars in philosophy and psychology, to place these conclusions in the context of the topic of this article, and to evaluate them critically.

Philosophers have been discussing the topic of human well-being and happiness for millennia. They have developed several theories on what well-being consists of and how it can be achieved, for example that well-being is based on the satisfaction of human needs and desires; that it can be judged based on an objective list of standards that are applied in deciding whether someone's life is good; and that it is relationships with other people that make life worthwhile.

Research in psychology has in the past focused on psychopathology, but recent studies changed their focus to determining which aspects of human functioning lead to psychological and subjective well-being. This new approach is termed positive psychology ${ }^{1}$. Şimşek argued that one of the most important goals of positive psychology should be to show what behaviour leads to well-being. ${ }^{2}$ One of the actions that may increase well-being is participation in religious activities. This is discussed in greater detail in part 3 below.

Martin EP Seligman and Mihaly Csikszentmihalyi, "Positive psychology: An introduction," American Psychologist 55(1), 2000:5-14.

2 Ömer F Şimşek, "Happiness Revisited: Ontological Well-being as a Theory-Based Construct of Subjective Well-being,” Journal of Happiness Studies 10(5), 2009:505-522. 


\section{Well-being}

Well-being is often defined as a contented state of being happy, healthy and prosperous. Koenig wrote that most people do not just try to avoid pain and conflict, but instead actively try to experience enjoyment, completeness, and meaning. ${ }^{3}$

The term well-being is often used in philosophy to describe what is good for a person or how well a person's life is going. ${ }^{4}$ Philosophers such as Aristotle use the Greek word

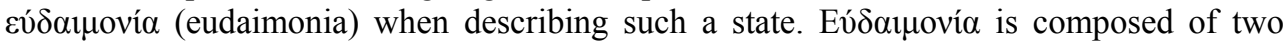

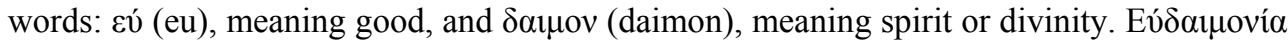

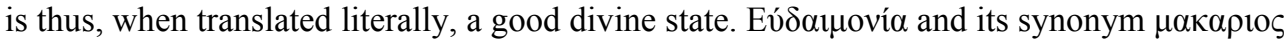
(blessedness) are often used to describe the condition of the gods. Most texts translate these

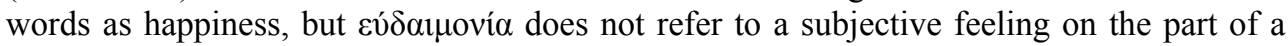
person. Translating it as well-being or flourishing human life comes closer to the meaning

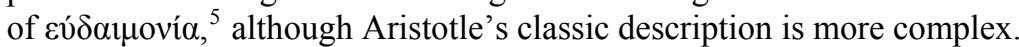

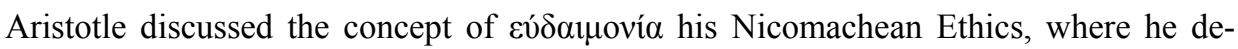
scribed it as doing and living well. He acknowledged that there is considerable difference of opinion on what exactly doing and living well consist of. Some think it is "some plain and obvious thing, like pleasure, wealth, or honour", but even they differ from each other and

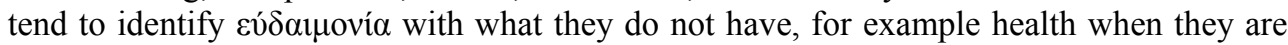
ill and wealth when they are poor. After evaluating other definitions he concludes that they

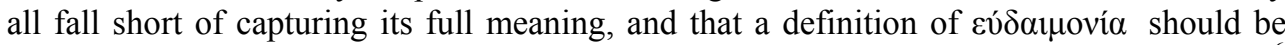
something final that is desirable in itself and not for the sake of obtaining something else. ${ }^{6}$ Taylor described this as a 'hypergood', the whole good life, or a combination of all good things in appropriate proportions.

Further thinking on the concept of well-being within the philosophical tradition is found in two main viewpoints, namely the satisfaction and actualisation theories. A third argument is that the goodness of life is dependent upon relationships with other persons. These different approaches are discussed in the following pages. Lastly I discuss a more recent hypothesis on well-being that focuses on the different aspects of a human being and the interdependence of those aspects, namely the Shalom Hypothesis.

\section{Satisfaction}

In describing his principle of greatest happiness, Bentham wrote that "nature has placed mankind under the governance of two sovereign masters, pain and pleasure. It is for them alone to point out what we ought to do." ${ }^{8}$ This is a good description of hedonism, where the things that make life worthwhile and enjoyable for a particular person are determined by that person's needs and desires. Well-being is about how a person experiences the quality of his/her life. Hedonism may be a plausible view of personal well-being, because what is good for us may be what we experience as good; and seeking pleasure and avoiding pain

Harold G Koenig, Michael E McCullough and David B Larson, Handbook of Religion and Health. Oxford: Oxford University Press, 2001:97.

4 Thomas Hurka, Perfectionism. New York: Oxford University Press, 1996:17.

5 Vincent Brümmer, "Ultimate Happiness and the Love of God" in Religion and the Good Life (ed.) M. Sarot and W. Stoker. Assen: Royal van Gorcum, 2004:241-265.

Aristotle, The Nicomachean Ethics (trans.) H Rackham: Hertfordshire: Wordsworth Editions, 1996:16-17.

Charles Taylor, Sources of the self: the making of the modern identity. Cambridge: Cambridge University Press, 1989:66.

8 Jeremy Bentham, Principles of Morals and Legislation. Amherst: Prometheus Books, 1988:1. 
usually do seem good to us. ${ }^{9}$ Hedonists believe that life has no objective meaning, and what makes life appealing varies from person to person.

Hegesias, a hedonist from the Cyrenaic school, taught that well-being is the absence of pain and sorrow. Hegesias was of the opinion that we should prefer death as the happy, pain-free alternative to suffering, and he was as a result nicknamed the death counsellor. His lectures at Alexandria led to so many suicides that King Ptolemy ordered him to stop teaching. It is ironic that a branch of hedonism, which set out to promote the pursuit of pleasure, produced a line of hedonist thinking that ended up advocating the end of all pursuits. $^{10}$

When pursuing satisfaction our needs and desires are in conflict with a hostile world. Sarot expanded on two strategies to address this conflict: optimising and adapting. In optimising we try to modify the world to suit our purposes. This is a popular strategy in the West today. ${ }^{11}$ Well-being is seen as something that can be attained by changing our circumstances, skills, opportunities and contacts in order to achieve what we wish.

Adapting, in contrast to optimisation, strives to adjust people's own desires to their situation. This line of reasoning accepts that our environment is hostile and cannot be controlled. Only by reducing our wants, desires and wishes will it be possible for us to satisfy them and become happy. Adapters maintain that the main problem of society is that people just want too much. Adapting is popular in Eastern cultures, but also played an important role in Western history. ${ }^{12}$

The apostle Paul seems to have lived according to the adaptation theory, for he wrote to the church in Philippi: "I have learned to be satisfied with what I have. I know what it is to be in need and what it is to have more than enough. I have learned this secret, so that anywhere, at any time, I am content, whether I am full or hungry, whether I have too much or too little. I have the strength to face all conditions by the power that Christ gives me."13

\section{Self-actualisation}

In the self-actualisation or perfectionist theory of the good life, for example in classical humanism, there is an objective list of standards that are applied in deciding when someone's life is good. An individual's personal views do not determine what those standards are. ${ }^{14}$ Socrates, Plato, Aristotle and the early Stoics provided one such objective standard by teaching that virtue supplies the necessary and sufficient conditions for

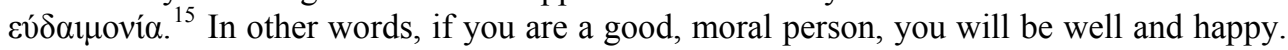
A person can therefore subjectively be unhappy as a result of thwarted desires, but based on objective standards, for example virtue, health, income, meaning and supportive friends, an outsider can judge that he/she has a high level of well-being.

\footnotetext{
Marcel Sarot. "Models of the good life" in Religion and the Good Life (ed.) by M Sarot and W Stoker. Assen: Koninklijke Van Gorcum. 2004:177.

10 Marcus T Cicero, Cicero's Tusculan Disputations. Also, Treatises on the Nature of the Gods, and on the Commonwealth (trans.) CD Yonge: New York: Harper \& Brothers. 1877:45.

Sarot, "Models," 178.

Sarot, "Models," 178.

Philippians 4:11-14 Good News Bible.

Sarot, "Models," 181.

15 Julia Annas, Oxford Studies in Ancient Philosophy: Volume VII. Oxford: Oxford University Press. 1989:97-98.
} 


\section{Fellowship}

The final theory of well-being outlined by Sarot is the fellowship theory of the good life, which advocates that it is healthy relationships with other persons that make a life worthwhile. Only in and through communion with other people can we become fully human. A life where fellowship is the ideal is more focused on other people and will most likely lead to receiving appreciation and positive feedback from people, which will increase well-being. ${ }^{16}$

\section{Shalom Hypothesis}

A more recently developed theory that encompasses elements from the satisfaction, selfactualisation and fellowship theories discussed above is that of the Dutch philosopher Dooyeweerd. ${ }^{17}$ Dooyeweerd developed an ontology of fifteen aspects of reality, each having a distinct core meaning, that form an ordered spectrum of meaning. The different aspects enable us to function, because each aspect has a set of laws to which entities respond. The fact that there is more than one aspect results in our experiencing diversity. Our functioning and experience can be logical and consistent as a result of the interrelationships among the aspects. ${ }^{18}$

Dooyeweerd contributed a basis for understanding the diversity and coherence of

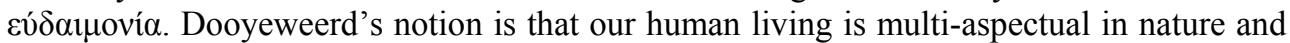
we function in all (or most) aspects, responding to each aspect's respective laws and there are repercussions of our functioning in each aspect. If we live according to the laws of an aspect, then the repercussions will be positive and will promote success, prosperity, health, etc. in that aspect, but if we go against the laws of an aspect then the repercussions will be negative in that aspect. Since all aspects are dependent upon one another and influence one another, it is necessary to function well in every aspect in order to achieve optimum wellbeing, success or prosperity. Functioning poorly in any aspect jeopardises the sustainability and success of the whole person. ${ }^{19}$

What Dooyeweerd scholars have recently named the 'Shalom Hypothesis' takes this further by stating that all the aspects work in harmony and we must function well in every aspect if we wish to achieve שָלוֹם This Hebrew word is used since there is no adequate English equivalent to express what is meant: a deep and lasting peace, health, prosperity and well-being, with strong overtones of completeness and wholeness. If we function poorly in any aspect, שָׁלוֹ is jeopardised. ${ }^{20}$ Basden summarised the result of well-being or dysfunction in some of these areas as follows: ${ }^{21}$

\footnotetext{
16 Sarot, "Models," 187.

17 Herman Dooyeweerd (1894-1977).

18 Herman Dooyeweerd, A New Critique of Theoretical Thought. Volume 4. (trans.) DH Freeman and W Young: Philadelphia: The Presbyterian and Reformed Publishing Company, 1953:4.

19 Andrew Basden, Philosophical frameworks for understanding information systems. Hershey: IGI Global, 2008:105-106.

20 Basden, Philosophical, 105.

21 Basden, Philosophical, 104-107.
} 


\begin{tabular}{|l|l|l|}
\hline Aspect & Well-being & Dysfunction \\
\hline Biotic & Health & Disease \\
\hline $\begin{array}{l}\text { Psychic or } \\
\text { Sensitive }\end{array}$ & Mental and sensory health and alertness & $\begin{array}{l}\text { Emotional } \\
\text { instability }\end{array}$ \\
\hline Analytical & Clear thinking, logical, good critique & Confusion \\
\hline Formative & Creativity, good planning and achieving & Laziness \\
\hline Lingual & Articulateness & Incoherence \\
\hline Social & Friendliness and respect, sociable & Hatred, disrespect \\
\hline Economic & Careful, frugal & $\begin{array}{l}\text { Waste, } \\
\text { squandering }\end{array}$ \\
\hline Aesthetic & $\begin{array}{l}\text { Enjoyment, rest, leisure, fun, harmony, } \\
\text { find everything interesting and beautiful }\end{array}$ & $\begin{array}{l}\text { Boredom, } \\
\text { ugliness }\end{array}$ \\
\hline Juridical & Justice & Injustice \\
\hline Ethical & Self-giving and generosity & Selfishness \\
\hline Pistic & $\begin{array}{l}\text { Commitment and loyalty, courage, high } \\
\text { morale, vision and faith }\end{array}$ & $\begin{array}{l}\text { Idolatry, } \\
\text { disloyalty, lack of } \\
\text { moral and ethical } \\
\text { values }\end{array}$ \\
\hline & & \\
\hline
\end{tabular}

\section{Psychological Factors}

Recent research in psychology started to focus on people's strengths and the positive methods that can improve well-being, rather than merely on the trials that people face in a psychopathology-oriented view of human functioning. As a result, positive psychology has emerged as a field within psychology that studies positive subjective experiences such as well-being, contentment, satisfaction in the past; hope and optimism for the future; and happiness in the present. ${ }^{22}$ Koenig, McCullough and Larson found that all sociodemographic factors combined predict less than $10 \%$ of the variance in well-being, which is too small to draw any real conclusions about the determinants of well-being. Researchers have therefore shifted their focus to the psychological factors that regulate the effects of external variables. ${ }^{23}$

Psychological factors such as optimism, purpose in life, high self-esteem and hope predict a much larger proportion of the variance in well-being. Two independent recent studies found that hope and meaning in life were strongly correlated with well-being. ${ }^{24}$ People's characters, motives, and values reflect their needs and those needs determine which areas of their lives have significance and meaning. Acting in line with your deeply held values and pursuing self-generated goals that match your needs (rather than purely adopted social norms and obligations) will lead to enhanced levels of well-being. ${ }^{25}$

Şimşek, “Happiness Revisited,” 515.

3 Harold G Koenig, Michael E McCullough and David B Larson, Handbook of Religion and Health (2nd ed.; Unpublished manuscript).

24 Koenig, McCullough and Larson, Handbook of Religion and Health (2nd ed.)

25 Jan Hofer, Holger Busch and Florian Kiessling, "Individual Pathways to Life Satisfaction: The Significance of Traits and Motives," Journal of Happiness Studies 9, 2008:503-517. 


\section{Emotions}

An important factor in evaluating well-being is whether people feel that, their lives taken as a whole, they experienced more pleasant or more unpleasant emotions. ${ }^{26}$

A last noteworthy opinion on the factors that influence well-being is that of Csikszentmihalyi, who said that people are happy when they are unselfconsciously involved in a task that absorbs them in a mindful challenge. He called this a state of 'flow.'27

\section{Christian Religion and Well-being}

The emotional benefits of religious belief have been widely accepted over the years. It is expected to lessen psychological distress, especially depression and anxiety, to provide comfort, alleviate pain and suffering, provide hope and meaning, and to help people cope with problems. The empirical evidence has not, however, always been conclusive that religion provides these benefits. ${ }^{28}$ The results of research and theories on the benefits of Christian religion are discussed in the following pages.

\section{Social Support}

The French sociologist Durkheim ${ }^{29}$ did research on how and why religion keeps believers from committing suicide. He found that individuals who were isolated and who were not active participants in family, religious, or other community groups, were more prone to suicide than people who were well integrated in society. ${ }^{30}$ Religious groups provide the necessary support, nurturing and integration to help people avoid what Durkheim called egoistic suicide. $^{31}$

Argyle points to recent studies that showed that people who were single, old, retired, or in poor health benefited more from church membership than others. This confirms that the social support provided by a church community is beneficial for some people. ${ }^{32}$ One study in particular found that engaging in organised religious activities provided older women with friendships, a sense of community, helped define their role in society and gave them a way of contributing to the welfare of others. There was a significant correlation between religious activities and the life satisfaction the interviewees reported. ${ }^{33}$ Merely attending church services does not, however, necessarily lead to increased well-being. It is active participation in church activities that enhances the member's social support system that is beneficial. $^{34}$

\footnotetext{
26 Lucas and Diener, "Subjective Well-Being," 471-484.

27 David G Myers, "The funds, friends and faith of happy people," American Psychologist 55, 2000:56-67.

28 Catherine E Ross, "Religion and Psychological Distress," Journal for the Scientific Study of Religion 29(2), 1990:236.

29 David Émile Durkheim (1858-1917).

30 Durkheim further argued that this is not the case in altruistic suicide, where coercion by and over-integration into a group leads to suicide that is regarded as an honourable escape. Peter Hamilton, Emile Durkheim: Critical Assessments, Volume 4. London: Routledge, 1990:157.

31 Ellen L Idler, "What Sociology can help us understand about Religion and Mental Health," in Handbook of Religion and Mental Health (ed.) HG Koenig. San Diego: Academic Press, 1998:51-58.

32 Michael Argyle, Psychology and Religion: An Introduction. New York: Routledge, 2000:141-154.

33 Christina M Neill and Arnold S Kahn, "The Role of Personal Spirituality and Religious Social Activity on the Life Satisfaction of Older Widowed Women," Sex Roles 40(3/4), 1999:319-329.

34 Lauren S Seifert, "Toward a Psychology of Religion, Spirituality, Meaning-Search, and Aging: Past Research and a Practical Application," Journal of Adult Development 9(1), 2002:61-70.
} 


\section{Life Satisfaction}

Having firm beliefs and existential certainty may lead to life satisfaction, especially for older and less educated individuals. Fundamentalists have been found to be more optimistic. The members of the fundamentalist Baptist churches in the United States, for example, have been found to be happier on average than members of more liberal churches. Belief in the after-life and faith in a supportive, caring God are strong predictors of happiness for the elderly, in particular, as it leads to a greater sense of control and hope. ${ }^{35}$

\section{Goals}

People often define themselves by what they want to do and who they want to be. In 2005 Emmons did a literary review of recent academic publications in Psychology and concluded that spiritual and religious goals, more so than other goals, seem to provide people with significant meaning and purpose for their lives. As long as they have religious and spiritual objectives people are likely to experience life as fulfilling, meaningful, and purposeful, even in the face of a deteriorating and disabling physical condition. ${ }^{36}$

Religion also seems to serve as a general unifying framework to bring about consistency in a person's diverse aspirations. Spiritual goals do not, however, necessarily guarantee emotional well-being. Emmons wrote that religion that results in excessive self-preoccupation, for example, may be detrimental for the well-being of that person and those around him/her. Goals that fulfil individualistic, but not collective objectives or societal needs may ultimately lead to a lower quality of life and the deterioration of interpersonal relationships. $^{37}$

\section{Coping Mechanisms}

Churches often impart emotional skills to their members and thus enhance and maintain their well-being. Two possible ways in which this may be achieved are, first, that members may have increased access to avenues for emotional disclosure and opportunities to share their burdens, as they may have greater access to counsellors and emotional support. Second, religions often promote exercises such as prayer, rituals, meditation, Sabbath rests, or morning devotionals that are effective in reducing stress, alleviating negative moods, and increasing positive moods. ${ }^{38}$

Religious coping methods found to be successful in promoting well-being consists of methods such as:

- seeking spiritual support;

- asking forgiveness from God and others;

- spiritual relationships with God and people;

- sacraments and purification rites;

- awareness of guidance and support by God;

- collaborative life management where God is a partner in decisions;

35 Argyle, Psychology and Religion: An Introduction, 141-154.

36 Robert A Emmons, "Striving for the Sacred: Personal Goals, Life Meaning, and Religion," Journal of Social Issues 61(4), 2005:731-745.

37 Emmons, "Striving for the Sacred," 742-743.

38 David Pizarro and Peter Salovey, "Religious Systems as 'Emotionally Intelligent' Organizations," Psychological Inquiry 13(3), 2002:221-222. 
- a positive perspective of negative events as being the will of God;

- seeking support from the congregation or clergy. ${ }^{39}$

Some people, however, habitually fall back on negative religious coping methods such as:

- spiritual discontent;

- thinking that negative events are God's punishment;

- feeling abandoned by God;

- discontent about relationships with other Christians;

- focusing on demonic powers;

- a reappraisal of God's powers. ${ }^{40}$

Negative religious coping methods reveal an unhealthy spirituality, involving a shaky relationship with God, spiritual struggle, fear of the world, and emotional distress such as depression and callousness towards others. Argyle therefore concluded that religion can be a source of distress as well as a source of successful solutions in coping. ${ }^{41}$ I would add to that conclusion that it is the mind-set, attitude and habits of the individual that determines whether religion is experienced as contributing or detracting from well-being.

\section{Physical and Mental Health}

Numerous studies have found a positive correlation between traditional Christian practices, such as regular worship attendance, Scripture reading, prayer, and positive mental and physical health among seniors. Religiously involved older adults are generally less prone to suicide, depression, anxiety, smoking and alcoholism, and are more satisfied with their lives, with a greater sense of well-being. Studies analysed by Argyle have found that older adults who practice their faith regularly have lower blood pressure, fewer heart attacks, stronger immune systems to fight diseases such as cancer, and are less likely to die of coronary artery disease. ${ }^{42}$ The emphasis is again on actively participating in Christian practices and not merely attending the services.

Religious healing may succeed in improving subjective health and subjective wellbeing. This is at least partly due to defining health as more than just the state of the body, and in embracing a happier view of life. Argyle wrote that, although in research studies religious healing events showed little or no immediate effects on objective health, in the studies that he reviewed the researchers expected that the effects were likely to improve in the longer term. ${ }^{43}$

\section{Effect on Behaviour}

In his research on how and why religion keeps believers from committing suicide, Durkheim concluded that religious groups make rules for many areas of life and that these rules have a stabilising effect on people, for example in lowering the rates of substance

39 Argyle, Psychology and Religion: An Introduction, 155-199; Kenneth I Pargament, et al. "Patterns of Positive and Negative Religious Coping with Major Life Stressors," Journal for the Scientific Study of Religion 37(4), 1998:710-724. 
abuse and extramarital affairs. ${ }^{44}$ Churches regulate the behaviour of their members ${ }^{45}$ and the rules of the church restrain individuals from following their own selfish desires, oblige them to consider the welfare of society and protect people from anomie. Individuals who do not have norms and guides for their behaviour are more prone to commit suicide than people with a strong sense of shared beliefs and moral attitudes. ${ }^{46}$

\section{Religious Experiences}

For some people transcendent experiences of timelessness and near-death form the basis of their belief in eternity and the after-life. Such spiritual encounters may convey a feeling of having been in contact with truth, something real, a powerful force, a transcendent being, and a feeling of unity with the whole of creation. It often leaves people with a sense of joy, a feeling of being more integrated, forgiven, a sense of timelessness and a desire to lead better lives and do more for others. ${ }^{47}$

\section{Concluding Remarks}

The previous pages provided an overview of some of the conclusions that have been reached by researchers and authors in philosophy, sociology and psychology. They have defined well-being as a contented state of being happy, healthy and prosperous and found that, instead of just trying to avoiding pain and conflict, most people strive to experience enjoyment, completeness and meaning. ${ }^{48}$

Within the philosophical tradition the satisfaction, actualisation and fellowship theories describe different viewpoints on what well-being is and how it can be achieved. The Shalom hypotheses combines these theories by stating that healthy functioning in all the different aspects of a human being, as well as in the interdependence of those aspects, are necessary for personal well-being.

Researchers in psychology have found that all socio-demographic factors combined predict less than $10 \%$ of the variance in well-being. As a result, researchers have recently started to focus on how people perceive the different factors that influence their well-being, for example their optimism and self-esteem. ${ }^{49}$

Research on the relationship between Christian religion and well-being has concluded that nurturing, non-punitive religion is associated with mental and physical health ${ }^{50}$ and that active participation in church activities that enhances the member's social support system is beneficial. ${ }^{51}$ Being part of a group with strong moral values has a stabilising effect on members and compels them to consider the welfare of others. ${ }^{52}$

Durkheim, Emil. Le suicide. Étude de sociologie. Paris: Alcan, 1897.

45 Durkheim found that Catholicism notably regulated and constrained the behaviour of their members more than Protestantism did. Idler, "Sociology," 51-58.

Argyle, Psychology and Religion: An Introduction, 60-75.

48 Koenig et al., Handbook of Religion and Health, 2001:97.

49 Lucas and Diener, "Subjective Well-Being", 477.

50 Argyle, Psychology and Religion: An Introduction, 155-199.

51 Seifert, "Toward a Psychology," 65.

52 Idler, "Sociology," 52-53. 


\section{BIBLIOGRAPHY}

Annas, Julia 1989. Oxford Studies in Ancient Philosophy: Volume VII. Oxford: Oxford University Press.

Argyle, Michael 2000. Psychology and Religion: An Introduction. New York: Routledge.

Aristotle 1996. The Nicomachean Ethics. Translated by H Rackham. Hertfordshire: Wordsworth Editions.

Basden, Andrew 2008. Philosophical frameworks for understanding information systems. Hershey: IGI Global.

Bentham, Jeremy 1988. Principles of Morals and Legislation. Amherst: Prometheus Books.

Brümmer, Vincent 2004. "Ultimate Happiness and the Love of God." Pages 241-265 in Religion and the Good Life. Edited by Marcel Sarot and Wessel Stoker. Assen: Royal van Gorcum.

Cicero, Marcus T 1877. Cicero's Tusculan Disputations. Also, Treatises on the Nature of the Gods, and on the Commonwealth. Translated by CD Yonge. New York: Harper $\&$ Brothers.

Durkheim, Emil 1897. Le suicide. Étude de sociologie. Paris: Alcan.

Dooyeweerd, Herman 1953. A New Critique of Theoretical Thought. Volume 4. Translated by DH Freeman and W Young. Philadelphia: The Presbyterian and Reformed Publishing Company.

Emmons, Robert A 2005. "Striving for the Sacred: Personal Goals, Life Meaning, and Religion." Journal of Social Issues 61(4). 731-745.

Hamilton, Peter 1990. Emile Durkheim: critical assessments, Volume 4. London: Routledge.

Hofer, Jan, Holger Busch, and Florian Kiessling 2008. "Individual Pathways to Life Satisfaction: The Significance of Traits and Motives." Journal of Happiness Studies 9. 503-520.

Hurka, Thomas 1996. Perfectionism. New York: Oxford University Press.

Idler, Ellen L 1998. "What Sociology can help us understand about Religion and Mental Health.” Pages 51-58 in Handbook of religion and mental health. Edited by Harold G Koenig. San Diego: Academic Press.

Koenig, Harold G 2001. Michael E McCullough, and David B Larson. Handbook of religion and health. Oxford: Oxford University Press.

Koenig, Harold G, Michael E, McCullough, and David B Larson 1998. Handbook of religion and health. (2nd ed.) Unpublished manuscript.

Lucas, Richard E, \& Ed Diener 2008. "Subjective Well-Being.” Pages 471-484 in Handbook of Emotions. (3rd ed.) Edited by M Lewis, and JM Haviland-Jones, and L Feldman Barrett. New York: Guilford.

Myers, David G 2000. "The funds, friends and faith of happy people." American Psychologist 55. 56-67.

Neill, Christina M \& Arnold S Kahn 1999. “The Role of Personal Spirituality and Religious Social Activity on the Life Satisfaction of Older Widowed Women." Sex Roles 40(3/4). 319-329. 
Pargament, Kenneth I, Bruce W Smith, Harold G Koenig \& Lisa Perez 1998. "Patterns of Positive and Negative Religious Coping with Major Life Stressors.” Journal for the Scientific Study of Religion 37(4). 710-724.

Pizarro, David \& Peter Salovey 2002. "Religious Systems as 'Emotionally Intelligent' Organizations.” Psychological Inquiry 13(3). 220-222.

Ross, Catherine E 1990. "Religion and Psychological Distress." Journal for the Scientific Study of Religion 29(2). 236-245.

Sarot, Marcel 2004. "Models of the good life." Pages 175-194 in Religion and the Good Life. Edited by Marcel Sarot \& Wessel Stoker. Assen: Koninklijke Van Gorcum.

Seifert, Lauren S 2002. "Toward a Psychology of Religion, Spirituality, Meaning-Search, and Aging: Past Research and a Practical Application." Journal of Adult Development 9(1). 61-70.

Seligman, Martin EP \& Mihaly Csikszentmihalyi 2000. "Positive psychology: An introduction." American Psychologist 55(1). 5-14.

Şimşek, Ömer F 2009. "Happiness Revisited: Ontological Well-being as a Theory-Based Construct of Subjective Well-being." Journal of Happiness Studies 10(5). 505-522.

Taylor, Charles 1989. Sources of the self: the making of the modern identity. Cambridge: Cambridge University Press. 